\section{Rate of Nitrogen Fertigation During Vegetative Growth and Spray Applications of Urea in the Fall Alters Growth and Flowering of Florists' Hydrangeas}

\author{
Guihong Bi ${ }^{1}$ \\ Truck Crops Branch Experiment Station, Mississippi State University, 2024
}

Experiment Station Road, P.O. Box 231, Crystal Springs, MS 39059

Carolyn F. Scagel

United States Department of Agriculture, Agricultural Research Service, Horticultural Crops Research Unit, 3420 NW Orchard Avenue, Corvallis, OR 97330

\author{
Richard Harkess \\ Department of Plant and Soil Sciences, Mississippi State University, 117 \\ Dorman Hall, Box 9555, Mississippi State, MS 39762
}

Additional index words. Hydrangea macrophylla 'Merritt's Supreme', foliar nitrogen

\begin{abstract}
Plants of Hydrangea macrophylla 'Merritt's Supreme' were fertigated with 0 , $70,140,210$, or $280 \mathrm{mg} \cdot \mathrm{L}^{-1}$ nitrogen $(\mathrm{N})$ from July to Sept. 2005 and sprayed with $0 \%$ or $3 \%$ urea in late October to evaluate whether plant $N$ status during vegetative growth influences plant performance during forcing. In late November, plants were manually defoliated, moved into a dark cooler $\left(4.4\right.$ to $\left.5.5^{\circ} \mathrm{C}\right)$ for 8 weeks, and then placed into a greenhouse for forcing. After budbreak, plants were supplied with either $0 \mathrm{~N}$ or 140 mg. $L^{-1} \mathbf{N}$ for 9 weeks. Plant growth and $N$ content were evaluated in Nov. 2005 before cold storage and plant growth, flowering, and leaf quality parameters were measured in late Apr. 2006. Increasing $N$ fertigation rate in 2005 significantly increased plant biomass by $\approx 14 \mathrm{~g}(26 \%)$ and plant $N$ content by $\approx 615 \mathrm{mg}(67 \%)$. Spray applications of urea (urea sprays) in the fall had no influence on plant biomass but significantly increased plant $\mathbf{N}$ content by $\approx 520 \mathrm{mg}\left(\mathbf{5 4 \%} \%\right.$. In general, plants grown with 210 and $280 \mathrm{mg} \cdot \mathrm{L}^{-1} \mathrm{~N}$ during 2005 had the greatest growth (total plant biomass, height), flowering (number of flowers, flower size), and leaf quality (leaf area, chlorophyll content) during forcing in 2006 . Urea sprays before defoliation increased plant growth, flowering, and leaf quality characteristics during forcing in 2006. Providing plants with $\mathbf{N}$ during the forcing period also increased plant growth, flowering, and leaf quality characteristics. Urea sprays in the fall were as effective as $\mathbf{N}$ fertilizer in the spring on improving growth and flowering. We conclude that both vegetative growth and flowering during forcing of 'Merritt's Supreme' hydrangea are influenced by both the $N$ status before forcing and $N$ supply from fertilizer during forcing. A combination of optimum rates of $\mathrm{N}$ fertigation during the vegetative stage of production with urea sprays before defoliation could be a useful management strategy to control excessive vegetative growth, increase $\mathbf{N}$ storage, reduce the total $\mathrm{N}$ input, and optimize growth and flowering of container-grown florists' hydrangeas.
\end{abstract}

Received for publication 16 Aug. 2007. Accepted for publication 28 Sept. 2007.

Contribution of the Mississippi Agricultural and Forestry Experiment Station Journal article no. $\mathrm{J}-11122$.

Mention of a trademark, proprietary product, or vendor does not constitute a guarantee or warranty of the product by the U.S. Department of Agriculture and does not imply its approval to the exclusion of other products or vendors that also may be suitable.

We thank Mark Terkanian, Keri L. Paridon, Peter Hudson, and Melvin Townsend for technical assistance and Natchez Trace Greenhouse, Kosciusko, MS, for plant material.

${ }^{1}$ To whom reprint requests should be addressed; e-mailgb250@msstate.edu
Most research on hydrangea nutrition has been focused on how fertilizer influences sepal coloration (Bailey, 1989; Dirr, 2004; Midcap, 1998).

To produce florists' hydrangea, many growers transplant rooted cuttings into 10 to $20 \mathrm{~cm}$ diameter (400 to $3100 \mathrm{~cm}^{3}$ volume) pots commonly applying liquid fertilizer with 100 to $175 \mathrm{mg} \cdot \mathrm{L}^{-1} \mathrm{~N}$ at each irrigation or 340 to $450 \mathrm{mg} \cdot \mathrm{L}^{-1} \mathrm{~N}$ every 7 to $10 \mathrm{~d}$ during the vegetative stage of production (Bailey, 1989). Plants are normally manually defoliated late in the growing season, stored in a cooler for 6 to 8 weeks, and then placed into the greenhouse for forcing. During the forcing stage, plants are normally supplied with liquid fertilizer containing 150 to $250 \mathrm{mg} \cdot \mathrm{L}^{-1}$ $\mathrm{N}$ at each irrigation or 340 to $450 \mathrm{mg} \cdot \mathrm{L}^{-1} \mathrm{~N}$ every 7 to $10 \mathrm{~d}$ during forcing (Bailey, 1989).

High-quality florists' hydrangea plants are usually full and compact in height. Chemical growth retardants are normally applied during the vegetative stage and the early period of forcing to control plant height (Bailey, 1989). An improved understanding of plant $\mathrm{N}$ requirements during vegetative and forcing stages of production would assist growers of florists' hydrangea in developing more efficient $\mathrm{N}$ fertilization practices using potentially less $\mathrm{N}$ and growth retardants.

In many species, leaves can contain up to $50 \%$ of the total $\mathrm{N}$ in a plant in late summer and early fall (Bi et al., 2007; Forshey, 1963). In deciduous plant species, $\approx 50 \%$ of the $\mathrm{N}$ in leaves moves from the leaves into stems and roots before natural defoliation (Kang and Titus, 1980; Shim et al., 1972; Spencer and Titus, 1972). The plant uses this stored $\mathrm{N}$ for new growth during the next growing cycle (Millard, 1995). Manual defoliation of florists' hydrangea before cold storage can help prevent the occurrence of diseases, especially botrytis bud rot (Bailey, 1989). However, because plants are usually defoliated when leaves are green, before $\mathrm{N}$ movement from leaves, they can lose a significant amount of $\mathrm{N}$. This decrease in stored $\mathrm{N}$ could potentially result in poor growth or plant performance during forcing.

Foliar fertilization in the fall is considered an alternative to supplying $\mathrm{N}$ to the soil of woody perennial nursery plants. Spray application of urea to deciduous plant species after terminal bud set increases $\mathrm{N}$ storage without stimulating new growth or delaying dormancy development (Bi et al., 2003; Cheng et al., 2002; Oland, 1960; Sanchez et al., 1990) and has the potential to decrease groundwater contamination resulting from soil nitrate leaching (Embleton et al., 1986). Based on the benefits reported for other species, spraying florists' hydrangea with urea before manual defoliation could potentially decrease overall $\mathrm{N}$ fertilizer input during production while maintaining or improving plant quality.

The objectives of this study were to determine: 1) how rate of $\mathrm{N}$ application during the vegetative stage of production influences plant growth; 2) whether plant $\mathrm{N}$ content before cold storage influences plant growth 
and flower development during forcing; and 3 ) whether urea sprays in the fall increase $N$ storage before cold storage and plant growth and flower development during forcing. Our goal is to develop a fertilization program that reduces excessive vegetative growth and improves flowering performance of container-grown florists' hydrangea without causing nutrient deficiency or reducing plant quality.

\section{Materials and Methods}

Plant culture, nitrogen treatments, and sampling. Rooted Hydrangea macrophylla 'Merritt's Supreme' cuttings were potted into Elite/Ultra Azalea pots $(17.8 \mathrm{~cm}$ diameter, $12.7 \mathrm{~cm}$ height, $2100 \mathrm{~cm}^{3}$ volume; ITML Horticultural Products Inc., Brantford, Ontario, Canada) containing Sun Gro \#4 (Sun Gro Horticulture, Bellevue, WA) in late May 2005. Each pot contained two cuttings that were pinched (leaving two nodes per shoot) twice during June. Plants were fertigated with $200 \mathrm{mg} \cdot \mathrm{L}^{-1} \mathrm{~N}$ using $20 \mathrm{~N}-4.4 \mathrm{P}-$ 16.6K fertilizer (TotalGro 20-10-20; SDT Industries, Winnsboro, LA) once every $3 \mathrm{~d}$ from early June to early July. Plants were grown outdoors under shadecloth $(40 \%$ shade) in Crystal Springs, MS (lat. $31^{\circ} 59^{\prime} \mathrm{N}$, long. $\left.90^{\circ} 21^{\prime} \mathrm{W}\right)$. On 25 July 2005,30 plants were randomly assigned to one of five groups (30 plants per $\mathrm{N}$ treatment $=150$ plants total) and fertilized two times per week for 5 weeks starting 25 July and then once per week for 4 weeks. At each fertigation, plants in each group received $400 \mathrm{~mL}$ of a modified Hoagland's solution (Hoagland and Arnon, 1950) containing one of five different $\mathrm{N}$ concentrations (N05 treatments: 0, 70, 140, 210 , or $280 \mathrm{mg} \cdot \mathrm{L}^{-1} \mathrm{~N}$ from $\mathrm{NH}_{4} \mathrm{NO}_{3}$ ). Plants were drip-irrigated as needed throughout the growing season and sprayed two times during July and once in August with 5000 ppm Daminozide [B-9, butanedioic acid mono (2,2-dimethylhydrazide), Crompton Manufacturing Co., Middlebury, CT] to control plant height.

Fifteen plants from each N05 treatment were randomly selected for one of two urea (U05) treatments and sprayed with 3\% urea using a backpack sprayer on 25 Oct. and 3 Nov. (+U treatment) and the remaining plants from each N05 treatment were sprayed with water as control (-U treatment). Plants were sprayed to the point of runoff on leaves. In late November, five plants from each N05 and urea treatment were harvested for assessment of plant growth (dry weight) and $\mathrm{N}$ content. Plants were destructively sampled and divided into stems, roots, and leaves. All samples were washed with double-distilled water to remove any urea residue from their surfaces and immediately put into a $60{ }^{\circ} \mathrm{C}$ forced-air oven, dried, then ground with a Wiley mill (40 mesh) for chemical analysis. Dry weight was recorded for each tissue type. The remaining plants were manually defoliated, placed into a dark cooler $\left(4.4\right.$ to $\left.5.5^{\circ} \mathrm{C}\right)$ for 8 weeks, then removed from the cooler, and placed into a greenhouse $\left(15.4{ }^{\circ} \mathrm{C}\right.$ night temperature $/ 23.7{ }^{\circ} \mathrm{C}$ vent temperature) for forcing using normal nursery practices.

After budbreak, plants from each N05 and U05 treatment were divided equally into two groups and fertilized two times per week for 9 weeks (N06 treatment). One group of plants was supplied with $400 \mathrm{~mL}$ of $\mathrm{N}$-free modified Hoagland's solution (-U-N and $+\mathrm{U}-\mathrm{N}$ treatments) and the other group of plants received $400 \mathrm{~mL}$ of modified Hoagland solution with $140 \mathrm{mg} \cdot \mathrm{L}^{-1} \mathrm{~N}$ from $\mathrm{NH}_{4} \mathrm{NO}_{3}(-\mathrm{U}+\mathrm{N}$ and $+\mathrm{U}+\mathrm{N}$ treatments). All plants received one spray application of B-9 $(2500 \mathrm{ppm})$ after three to five leaf pairs had unfolded.

During flowering in late April, plant height (measured from top of pot to top of the inflorescence) and the number of inflorescences was recorded. Plants were harvested and separated into leaves, stems, flowers, and roots. Total leaf area (in centimeters squared) of each plant was measured using a LICOR Model LI-3100C Area Meter (LICOR Environmental, Lincoln, NE). Total leaf chlorophyll content (in milligrams per decimeter squared) was determined spectrophotometrically according to Arnon (1949). All samples were washed in double-distilled water, immediately put into a $60{ }^{\circ} \mathrm{C}$ oven, and dried. Dry weight was recorded for each tissue type.

Experimental design and statistical analyses. The experiment layout was completely randomized with each treatment unit (pot) replicated five times for each N05 treatment $(0 \mathrm{~N}, 70 \mathrm{~N}, 140 \mathrm{~N}, 210 \mathrm{~N}, 280 \mathrm{~N}), \mathrm{U} 05$ treatment $(+\mathrm{U},-\mathrm{U})$, and $\mathrm{N} 06$ treatment $(+\mathrm{N}$, $-\mathrm{N})$. Data from 2005 were analyzed in a factorial design using analysis of variance (ANOVA) with N05 treatment and urea treatment as factors. Data from 2006 were analyzed in a factorial design using ANOVA with N05 treatment, urea treatment, and N06 treatment as factors. Where indicated by ANOVA, means were separated using Tukey's honestly significant difference $\left(\mathrm{THSD}_{0.05}\right)$ at $P=0.05$. Means of interactions are only presented when indicated as significant $(P<0.05)$ by ANOVA. Plant response to N05 treatments was evaluated using linear and quadratic polynomial contrasts based on the $\mathrm{N}$ fertigation in 2005. All analyses were performed using Statistica (Statsoft, Tulsa, OK).

\section{Results and Discussion}

2005 growth. Increasing rate of $\mathrm{N}$ fertigation in 2005 (N05 treatment) significantly increased total plant biomass by $\approx 14 \mathrm{~g}(26 \%)$ and biomass in roots, stems, and leaves (Fig. 1). Foliar applications of urea in the fall had no influence on plant biomass (data not shown). Rate of $\mathrm{N}$ fertigation in 2005 and urea treatment had no influence on biomass allocation between roots and shoots (ratio of roots to aboveground was $\approx 0.40$ across all treatments). With several other deciduous plant species, low soil availability of $\mathrm{N}$ has been reported to increase root/shoot $(\mathrm{R} / \mathrm{S})$ ratio to maximize uptake of available nutrients (Millard and Neilsen, 1989). In our study, all plants received the same amount of $\mathrm{N}$ for 5 weeks until July when N05 treatments started, after which N05 treatments were applied for only 9 weeks. It is possible that plants may not have been exposed to N05 treatments for long enough to change $\mathrm{R} / \mathrm{S}$ ratios. Similar R/S ratios between plants in different N05 treatments might also be the result of the effects of B-9 on R/S ratios. Chemicals used as plant growth retardants such as B-9 can inhibit stem internode elongation, but also can inhibit or stimulate root growth (Pan and Zhao, 1993). In radish, the a.i. in B- 9 can increase $R / S$ ratios by decreasing shoot weight and increasing root weight (Thompson et al., 1983).

$2005 N$ concentrations and contents. Increasing rate of $\mathrm{N}$ fertigation in 2005 (N05 treatment) and urea sprays in the fall increased $\mathrm{N}$ concentrations in stems and leaves (Table 1). The effect of urea sprays on root $\mathrm{N}$ concentrations was greater when plants were fertigated with low $\mathrm{N}$ rates than in those fertigated with high $\mathrm{N}$ levels (Fig. 2). $\mathrm{N}$ concentrations in the roots of plants treated with urea were similar across all five $\mathrm{N}$ fertigation rates.

Increasing rate of $\mathrm{N}$ fertigation in 2005 (N05 treatment) increased total plant N content and $\mathrm{N}$ contents in all plant structures (Fig. 3A). Plants grown at the highest N05 rate contained $\approx 615 \mathrm{mg}(67 \%)$ more $\mathrm{N}$ than plants grown at the lowest N05 rate. Urea sprays in the fall significantly increased $\mathrm{N}$ contents in all plant structures and increased total plant $\mathrm{N}$ by $\approx 520 \mathrm{mg}$ (54\%) (Fig. 3B). Approximately $47 \%$ to $53 \%$ of total plant $\mathrm{N}$ was in leaves. $\mathrm{N}$ allocation between roots and shoots was not influenced by rate of N05 fertigation or urea sprays (data not shown).

The ability of foliar applications of urea in the fall to increase plant $\mathrm{N}$ content without increasing growth has been demonstrated with several plant species (Bi et al., 2003; Cheng et al., 2002; Cheng and Xia, 2004).

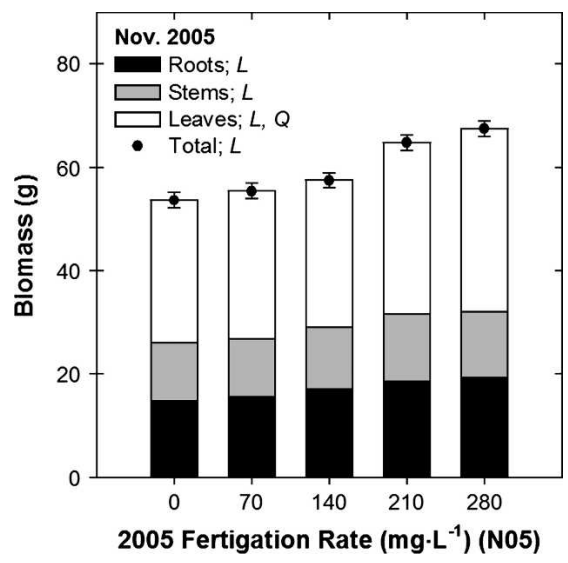

Fig. 1. Biomass of Hydrangea macrophylla 'Merritt's Supreme' grown at five rates of nitrogen (N) fertigation in 2005 (N05 rate). Data were collected in Nov. 2005. Error bars on total biomass data points represent SES $(\mathrm{n}=10)$. Nonsignificant $(P>0.05)$ and significant $(P<$ $0.05)$ linear $(L)$ and quadratic $(Q)$ contrasts across N05 rates denoted in legend. 
Table 1. Influence of nitrogen $(\mathrm{N})$ fertigation rate in 2005 (N05) and urea sprays in the fall of 2005 (U05) on N concentrations of stems and leaves of Hydrangea macrophylla Merritt's Supreme in Nov. 2005.

\begin{tabular}{lcc}
\hline & \multicolumn{2}{c}{ N concn (\%) } \\
\cline { 2 - 3 } Treatments $^{\mathrm{z}}$ & Stems & Leaves \\
\hline N05 & 1.59 & 1.64 \\
0 & 1.90 & 1.83 \\
70 & 1.92 & 2.12 \\
140 & 1.99 & 2.15 \\
210 & 2.17 & 2.33 \\
280 & $(0.041)$ & $(0.045)$ \\
SE $^{\mathrm{y}}$ & $L$ & $L$ \\
Contrasts & \\
U05 & & \\
-U & $1.54 \mathrm{a}^{\mathrm{w}}$ & $1.60 \mathrm{a}$ \\
$+\mathrm{U}$ & $2.49 \mathrm{~b}$ & $2.22 \mathrm{~b}$ \\
SE & $(0.026)$ & $(0.028)$ \\
\hline
\end{tabular}

${ }^{\mathrm{z}} \mathrm{N} 05=$ rate of $\mathrm{N}$ fertigation in $2005(0,70,140$, 210 , and $\left.280 \mathrm{mg} \cdot \mathrm{L}^{-1}\right) ; \mathrm{U} 05=$ plants sprayed with $3 \%$ urea $(+\mathrm{U})$ or water $(-\mathrm{U})$.

${ }^{\mathrm{N}} \mathrm{N} 05, \mathrm{n}=10 ; \mathrm{U} 05, \mathrm{n}=25$.

${ }^{\times}$Significant $(P<0.05)$ linear $(L)$ and quadratic $(Q)$ contrasts across $\mathrm{N} 05$ rates.

${ }^{\text {w}}$ Means denoted by the same letter are not significantly different $\left(\mathrm{THSD}_{0.05}\right)$.

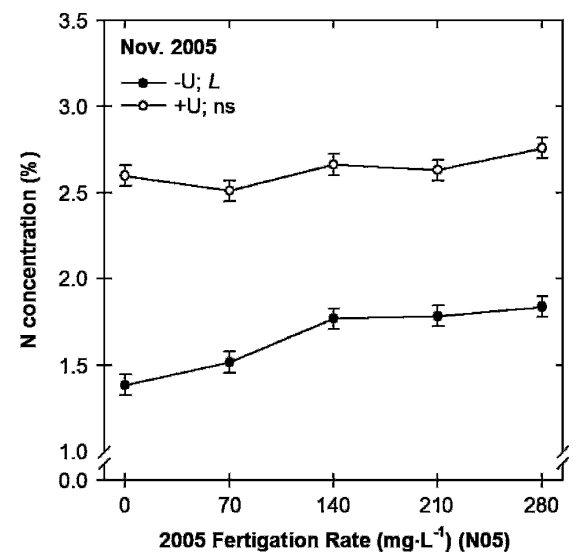

Fig. 2. Nitrogen concentrations in roots of Hydrangea macrophylla 'Merritt's Supreme' grown at five rates of nitrogen $(\mathrm{N})$ fertigation in 2005 (N05 rate) and sprayed (+U) or not (-U) with $3 \%$ urea in the fall of 2005 (U05). Error bars on data point represent SES $(\mathrm{n}=5)$. Nonsignificant $(P>0.05)$ and significant $(P<0.05)$ linear $(L)$ and quadratic $(Q)$ contrasts across N05 rates denoted in legend.

Use of urea sprays to increase plant $\mathrm{N}$ status has several practical implications to hydrangea production. With other plants species, a proportion of the $\mathrm{N}$ taken up from soil fertigation during the growing season is used for structural growth, and $\mathrm{N}$ uptake in the fall contributes more to storage and subsequent remobilization of $\mathrm{N}$ the next spring than $\mathrm{N}$ uptake during summer (Millard, 1996). In florists' hydrangea, excessive fertilization during the vegetative stage of production could cause vigorous growth and reduced plant quality (Bailey, 1989). Furthermore, plants receiving high amounts of $\mathrm{N}$ fertilizer from soil throughout late summer and fall tend to keep growing late into the season and have delayed dormancy (Bramlage et al.,
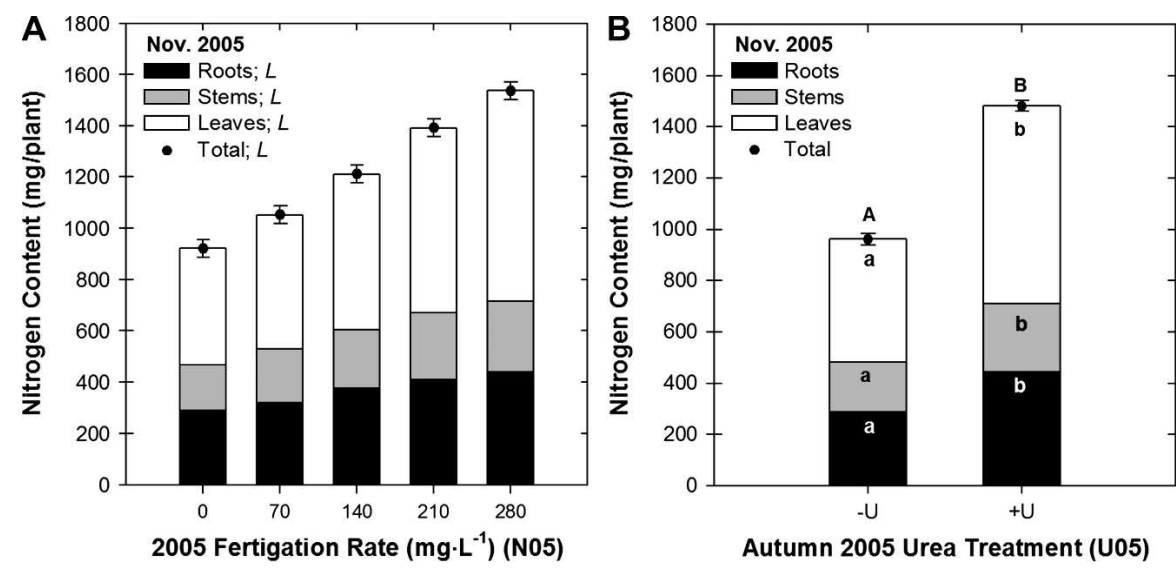

Fig. 3. Nitrogen content of Hydrangea macrophylla 'Merritt's Supreme' grown at five rates of nitrogen (N) fertigation in 2005 (N05 rate) and sprayed (+U) or not (-U) with $3 \%$ urea in the fall of 2005 (U05). Data were collected in Nov. 2005. (A) Significant $(P<0.05)$ linear $(L)$ and quadratic $(Q)$ contrasts across N05 rates denoted in legend. (B) Column segments within a plant structure denoted with different lower case letters are significantly different $\left(\mathrm{THSD}_{0.05}\right)$. Columns denoted with different upper case letter are significantly different $\left(\mathrm{THSD}_{0.05}\right)$. Error bars on total biomass data points represent SES $(\mathrm{A}, \mathrm{n}=$ $10 ; \mathrm{B}, \mathrm{n}=25)$.
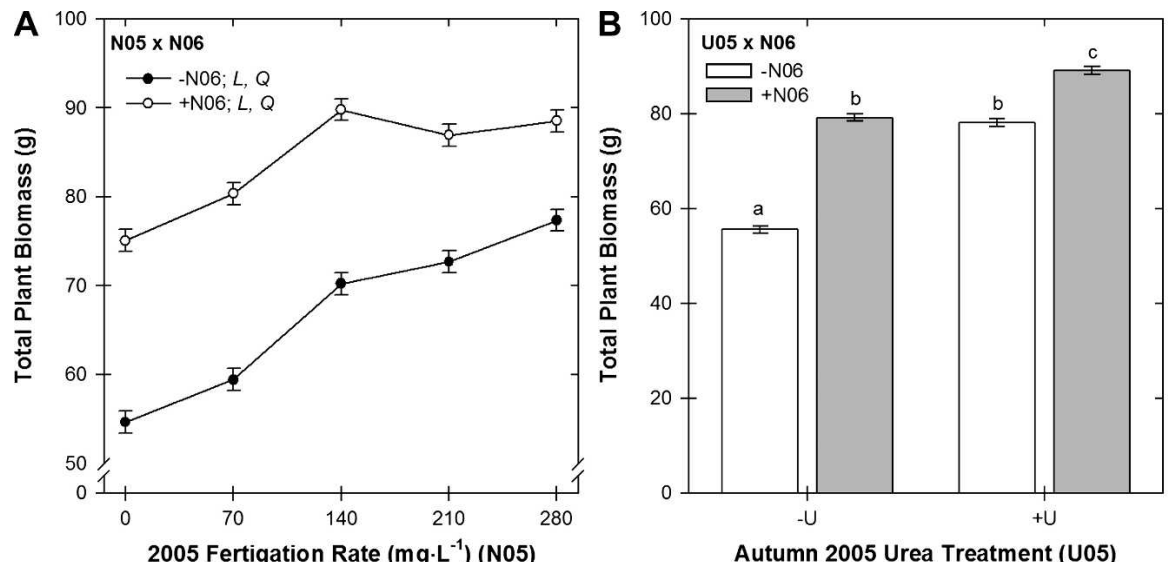

Autumn 2005 Urea Treatment (U05)
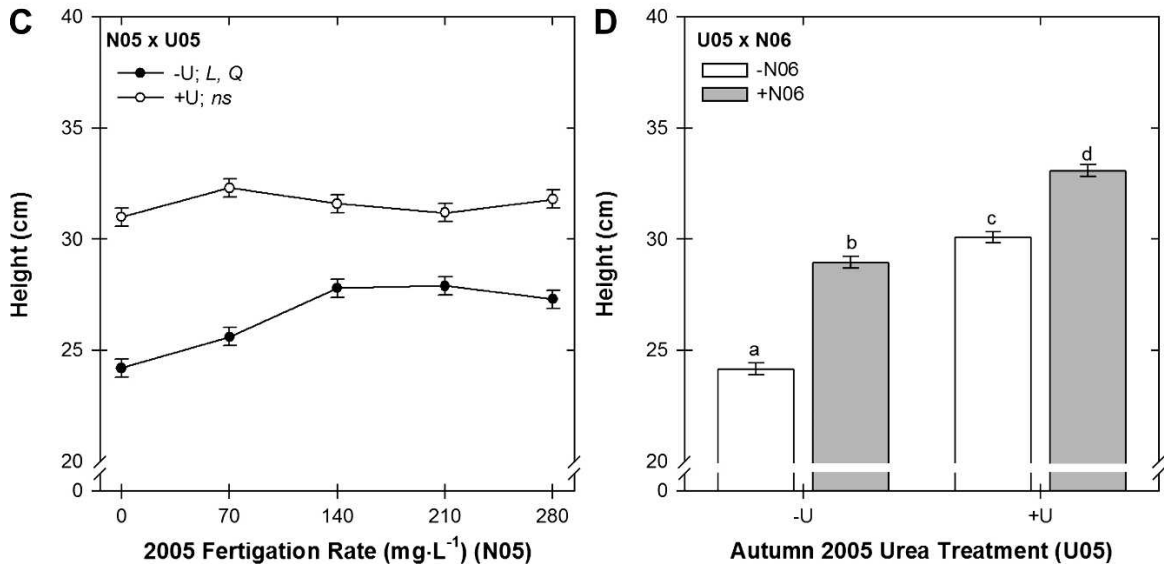

Fig. 4. Total plant dry weight (A-B) and height (C-D) of Hydrangea macrophylla 'Merritt's Supreme' in 2006. Plants were grown at five rates of nitrogen $(\mathrm{N})$ fertigation in 2005 (N05 rate), sprayed (+U) or not $(-\mathrm{U})$ with $3 \%$ urea in the fall of 2005 (U05), and received no $\mathrm{N}$ fertilizer $(-\mathrm{N})$ or $140 \mathrm{mg} \cdot \mathrm{L}^{-1} \mathrm{~N}$ fertilizer $(+\mathrm{N})$ the next spring $(\mathrm{N} 06)$. Means of interactions are presented when indicated as significant $(P<$ $0.05)$ by analysis of variance. $(\mathbf{A}-\mathbf{C})$ Significant $(P<0.05)$ linear $(L)$ and quadratic $(Q)$ contrasts across N05 rates denoted in legend. (B-D) Columns denoted with different lower case letters are significantly different $\left(\mathrm{THSD}_{0.05}\right)$. Error bars represent $\operatorname{SES}(\mathrm{A}, \mathrm{C}, \mathrm{n}=10 ; \mathrm{B}, \mathrm{D}, \mathrm{n}=25)$.

1980; Millard, 1995). Our results indicate that foliar urea application later in the season can significantly increase plant $\mathrm{N}$ status without affecting plant size. Therefore, com- bining a low to moderate rate of $\mathrm{N}$ fertigation during the vegetative stage of production with urea sprays before cold storage may result in plants with adequate but not excessive 

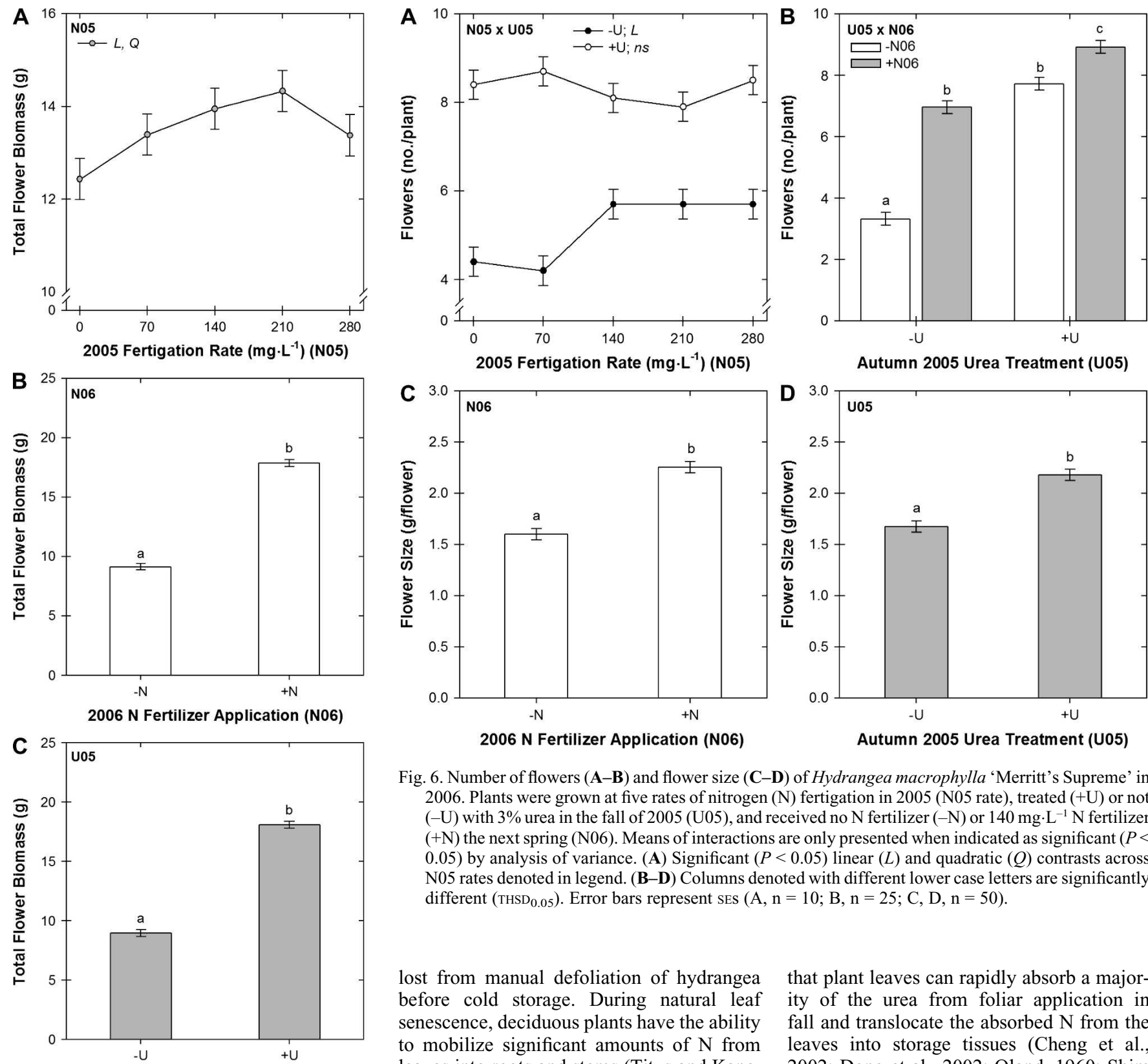

Autumn 2005 Urea Treatment (U05)

Fig. 5. Flower dry weight of Hydrangea macrophylla 'Merritt's Supreme' in 2006. Plants were grown at five rates of nitrogen $(\mathrm{N})$ fertigation in 2005 (N05 rate), sprayed (+U) or not $(-\mathrm{U})$ with $3 \%$ urea in the fall of 2005 (U05), and received no $\mathrm{N}$ fertilizer $(-\mathrm{N})$ or 140 $\mathrm{mg} \cdot \mathrm{L}^{-1} \mathrm{~N}$ fertilizer $(+\mathrm{N})$ the next spring. (A) Significant $(P<0.05)$ linear $(L)$ and quadratic $(Q)$ contrasts across N05 rates denoted in legend. (B-C) Columns denoted with different lower case letters are significantly different $\left(\mathrm{THSD}_{0.05}\right)$. Error bars represent SES $(\mathrm{A}, \mathrm{n}=20$; $\mathrm{B}, \mathrm{C}, \mathrm{n}=50$ ).

plant growth during the vegetative stage and increased $\mathrm{N}$ status compared with plants that receive no urea. This strategy also has the potential to improve dormancy development and reduce overall use of $\mathrm{N}$ fertilizers and chemical growth retardants.

Spray application of urea in the fall may also be a useful strategy for replacing the $\mathrm{N}$

Fig. 6. Number of flowers (A-B) and flower size (C-D) of Hydrangea macrophylla 'Merritt's Supreme' in 2006. Plants were grown at five rates of nitrogen (N) fertigation in 2005 (N05 rate), treated (+U) or not $(-\mathrm{U})$ with $3 \%$ urea in the fall of 2005 (U05), and received no N fertilizer $(-\mathrm{N})$ or $140 \mathrm{mg} \cdot \mathrm{L}^{-1} \mathrm{~N}$ fertilizer $(+\mathrm{N})$ the next spring (N06). Means of interactions are only presented when indicated as significant $(P<$ $0.05)$ by analysis of variance. (A) Significant $(P<0.05)$ linear $(L)$ and quadratic $(Q)$ contrasts across N05 rates denoted in legend. (B-D) Columns denoted with different lower case letters are significantly different $\left(\mathrm{THSD}_{0.05}\right)$. Error bars represent SES $(\mathrm{A}, \mathrm{n}=10 ; \mathrm{B}, \mathrm{n}=25 ; \mathrm{C}, \mathrm{D}, \mathrm{n}=50)$.

lost from manual defoliation of hydrangea before cold storage. During natural leaf senescence, deciduous plants have the ability to mobilize significant amounts of $\mathrm{N}$ from leaves into roots and stems (Titus and Kang, 1982). In apple, $N$ mobilization during leaf senescence constitutes $\approx 25 \%$ of the total tree $\mathrm{N}$ (Cheng et al., 2002). There is a positive relationship between the level of storage $\mathrm{N}$ and initial spring growth in many species $(\mathrm{Bi}$ et al., 2003; Cheng and Fuchigami, 2002; Taylor et al., 1975). Therefore, it is important to achieve maximum mobilization and withdrawal of $\mathrm{N}$ from senescing leaves before abscission (Millard, 1995). However, earlier defoliation causes abscission of green leaves before any significant $\mathrm{N}$ withdraw occurs. This can cause a decrease in $\mathrm{N}$ reserves and reduce the amount of $\mathrm{N}$ available for new growth the next season (Guak et al., 2001) and can decease yield (Howell et al., 1978; Scholefield et al., 1978). In our study, hydrangea leaves contained $47 \%$ to $53 \%$ of the total $\mathrm{N}$ in the plant when manual defoliation occurred. The $\mathrm{N}$ lost resulting from manual defoliation could potentially result in poor plant growth and flower development during forcing. Several studies have shown that plant leaves can rapidly absorb a majority of the urea from foliar application in fall and translocate the absorbed $\mathrm{N}$ from the leaves into storage tissues (Cheng et al., 2002; Dong et al., 2002; Oland, 1960; Shim et al., 1972). In our study, plants sprayed with urea contained $\approx 226 \mathrm{mg}(47 \%)$ more $\mathrm{N}$ in stems and roots than plants that did not receive urea spray. This increased $\mathrm{N}$ from foliar urea application could compensate the $\mathrm{N}$ lost from manual defoliation and potentially improve plant growth and flower development during forcing.

2006 vegetative growth and flowering. Total plant dry weight and height increased with increasing rate of $\mathrm{N}$ fertigation from the previous year (N05 treatment) and plants grown at $\mathrm{N} 05$ rates of $210 \mathrm{mg} \cdot \mathrm{L}^{-1}$ or greater had similar total biomass and plants grown at N05 rates of 140 to $280 \mathrm{mg} \cdot \mathrm{L}^{-1}$ had similar height in 2006 (Figs. 4A and C). Urea sprays in the fall of 2005 increased total plant biomass and height in 2006 (Figs. 4B and D) and plants grown at N05 rates less than $140 \mathrm{mg} \cdot \mathrm{L}^{-1}$ were more responsive to urea sprays in terms of plant height compared with plants grown at higher N05 rates (Fig. 4C). Application of $\mathrm{N}$ to soil in the spring (N06 
treatment) increased total plant biomass and plant height in 2006 (Figs. 4B and D). Biomass of plants grown at N05 rates less than $210 \mathrm{mg} \cdot \mathrm{L}^{-1}$ was more responsive to $\mathrm{N}$ application in the spring compared with plants grown at higher $\mathrm{N}$ rates (Fig. 4A).

Total flower dry weight (flower biomass/ plant) increased with increasing rate of $\mathrm{N}$ fertigation from the previous year (N05 treatment) and plants grown at the N05 rate of $210 \mathrm{mg} \cdot \mathrm{L}^{-1}$ had the greatest flower biomass (Fig. 5A). Urea sprays in the fall of 2005 and $\mathrm{N}$ application during the spring of 2006 increased flower biomass (Figs. 5B and C) and flower production (flowers/plant) (Fig. 6B). Flower production of plants in the $-\mathrm{U}$ treatment increased with increasing rate of $\mathrm{N}$ fertigation from the previous year (N05 treatment), but flower production of plants in the $+\mathrm{U}$ treatment was not influenced by N05 rate (Fig. 6A). In general, urea sprays in the fall of 2005 and $\mathrm{N}$ application during the spring of 2006 increased flower size (dry weight/flower) and rate of $\mathrm{N}$ fertigation in 2005 had no influence on flower size (Figs. 6C and D).

Total leaf area increased with increasing rate of $\mathrm{N}$ fertigation from the previous year (N05 treatment) and plants grown at N05 rates of $210 \mathrm{mg} \cdot \mathrm{L}^{-1}$ or greater had similar leaf area in 2006 (Figs. 7A and C). Urea sprays in the fall of 2005 increased total leaf area in 2006 (Fig. 7E) and plants grown at N05 rates less than $210 \mathrm{mg} \cdot \mathrm{L}^{-1}$ were more responsive to urea sprays compared with plants grown at higher N05 rates (Fig. 7A). Application of $\mathrm{N}$ to soil in the spring (N06 treatment) increased leaf area in 2006 (Fig. 7E) and plants grown at $\mathrm{N} 05$ rates less than $140 \mathrm{mg} \cdot \mathrm{L}^{-1}$ were more responsive to $\mathrm{N}$ application in the spring (Fig. 7C). Chlorophyll content of leaves increased with increasing rate of $\mathrm{N}$ fertigation from the previous year (N05 treatment) (Fig. 7B). Urea sprays in the fall of 2005 and $\mathrm{N}$ application during the spring of 2006 also increased leaf chlorophyll content (Figs. 7D and F).

Our results indicate that, in general, $\mathrm{N}$ rates between 210 and $280 \mathrm{mg} \cdot \mathrm{L}^{-1}$ during the vegetative stage of production can result in similar growth (total biomass and height), flowering (number of flowers and flower size), and leaf quality (leaf area and chlorophyll content) during forcing. Urea sprays in the fall and $\mathrm{N}$ applications during the spring can improve growth, flowering, and leaf quality during forcing. Interestingly, plants in the $+\mathrm{U}-\mathrm{N}$ treatment had similar growth, flower production, and leaf area as plants in the $-\mathrm{U}+\mathrm{N}$ treatment (Figs. 4, 6, and 7). This indicates that spraying container-grown florists' hydrangea in the fall with urea may be useful for decreasing $\mathrm{N}$ applications during forcing.

In many perennial species, early spring growth is primarily supported by remobilization of stored $\mathrm{N}$, and this remobilization of $\mathrm{N}$ provides a large proportion of the annual $\mathrm{N}$ supply required to support plant new growth and development and allow plants to make the most efficient use of available
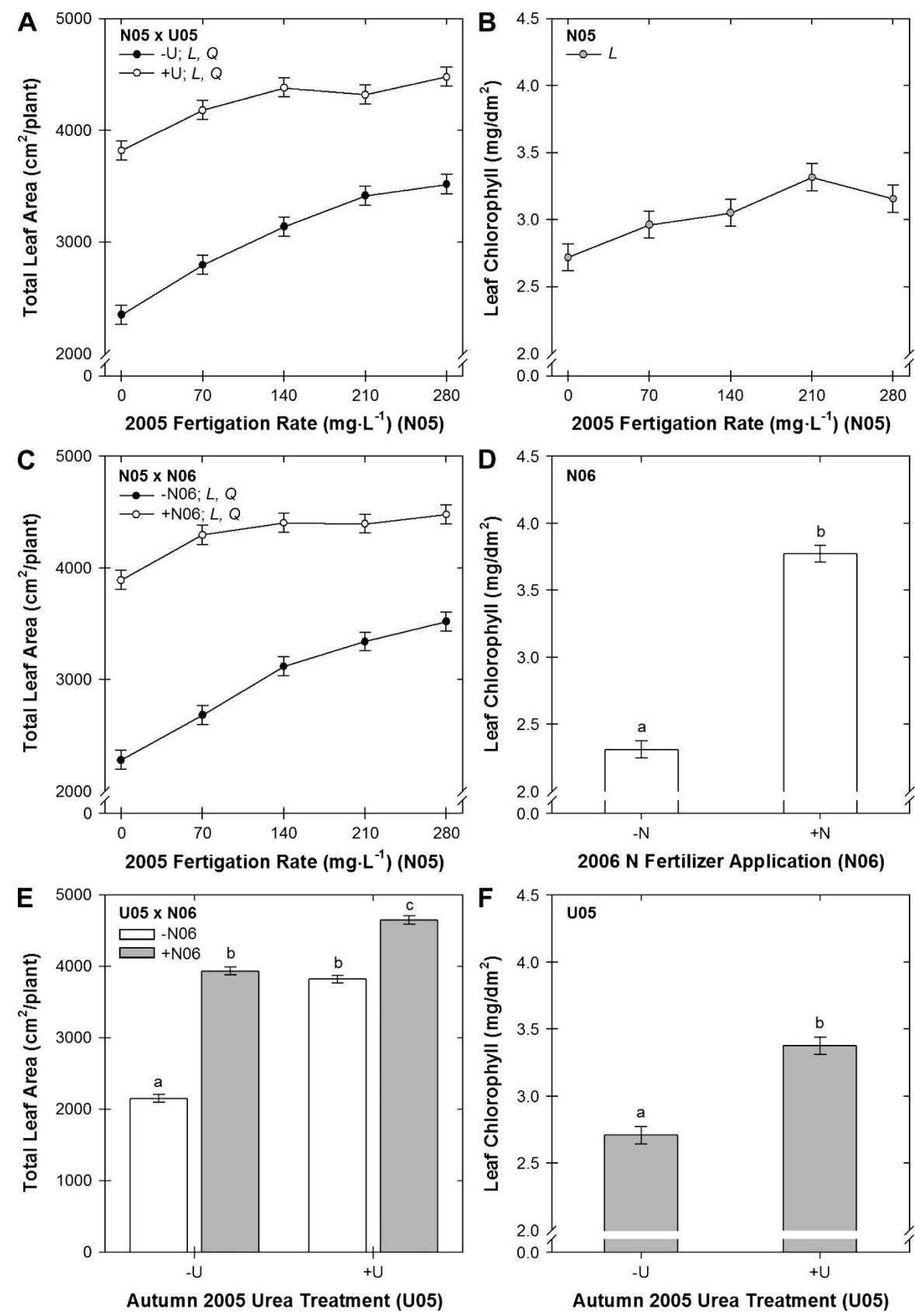

Fig. 7. Total leaf area $(\mathbf{A}, \mathbf{C}, \mathbf{E})$ and leaf chlorophyll content $(\mathbf{B}, \mathbf{D}, \mathbf{F})$ of Hydrangea macrophylla 'Merritt's Supreme' in 2006. Plants were grown at five rates of nitrogen (N) fertigation in 2005 (N05 rate), sprayed $(+\mathrm{U})$ or not $(-\mathrm{U})$ with $3 \%$ urea in the fall of 2005 (U05), and received no N fertilizer $(-\mathrm{N})$ or $140 \mathrm{mg} \cdot \mathrm{L}^{-1} \mathrm{~N}$ fertilizer $(+\mathrm{N})$ the next spring (N06). Means of interactions are only presented when indicated as significant $(P<0.05)$ by analysis of variance. $(\mathbf{A}-\mathbf{C})$ Significant $(P<0.05)$ linear $(L)$ and quadratic $(Q)$ contrasts across N05 rates denoted in legend. (D-F) Columns denoted with different lower case letters are significantly different $\left(\mathrm{THSD}_{0.05}\right)$. Error bars represent $\mathrm{SES}(\mathrm{A}, \mathrm{C}, \mathrm{n}=10 ; \mathrm{B}, \mathrm{n}=20$; $\mathrm{E}, \mathrm{n}=25 ; \mathrm{D}, \mathrm{F}, \mathrm{n}=50$ ).

nutrient resources (Bi et al., 2003; Cheng and Xia, 2004; Millard, 1995). The relationship between increased plant $\mathrm{N}$ content from foliar applications of urea in the fall and growth the next spring has been reported on several plant species (Bi et al., 2003; Cheng and Xia, 2004; O'Kennedy et al., 1975). In apple nursery trees, foliar urea applications after terminal bud set can improve $\mathrm{N}$ reserves and transplanting performance (Cheng and Fuchigami, 2002). One-year-old grapevines sprayed with foliar urea in the previous fall produced a larger total leaf area, a higher fruit yield, more fruits per vine, larger fruit, and a higher total vine dry weight the next year than those that were not sprayed with foliar urea (Cheng and Xia, 2004). Spraying hydrangea with either urea in the fall before defoliation or applying $\mathrm{N}$ fertilizer during forcing had similar effects on flower production and flower size, suggesting that urea sprays in the fall can be as effective as $\mathrm{N}$ applications during forcing to increase flower number and flower size. 
In conclusion, $\mathrm{N}$ status of container-grown florists' hydrangea during the vegetative stage of production influences both vegetative growth and flowering during forcing. Spraying plants with urea in the fall before defoliation improves growth and flowering performance of florists' hydrangea during forcing, and $\mathrm{N}$ application during forcing also plays an important role in sustaining plant growth and flower development. Although urea sprays in the fall have the potential to improve $\mathrm{N}$ storage, decrease overall fertilizer input, and optimize growth during production of container-grown florists' hydrangeas, the optimum rates and timing of urea applications still need to be evaluated.

\section{Literature Cited}

Arnon, D.I. 1949. Copper enzymes in isolated chloroplasts. Polyphenoloxidase in Beta vulgaris. Plant Physiol. 24:1-15.

Bailey, D.A. 1989. Hydrangea production. Timber Press, Portland, OR.

Bi, G., C.F. Scagel, L. Cheng, S. Dong, and L.H. Fuchigami. 2003. Spring growth of almond nursery trees depends upon both nitrogen reserves and spring nitrogen application. J. Hort. Sci. Biotechnol. 78:853-858.

Bi, G., C.F. Scagel, L.H. Fuchigami, and R.P. Regan. 2007. Differences in growth, and nitrogen uptake and storage between two containergrown cultivars of rhododendron. J. Environ. Hort. 25:13-20.

Bramlage, W.J., M. Drake, and W.J. Lord. 1980. The influence of mineral nutrition on the quality and storage performance of pome fruits grown in North America, p. 29-39. In: Atkinson, D., J.E. Jackson, R.O. Sharples, and W.N. Waller (eds.). Mineral nutrition of fruit trees. Butterworths, London.

Cheng, L. and L.H. Fuchigami. 2002. Growth of young apple trees in relation to reserve nitrogen and carbohydrates. Tree Physiol. 22:1297-1303.

Cheng, L., S. Dong, and L.H. Fuchigami. 2002. Urea uptake and nitrogen mobilization by apple leaves in relation to tree nitrogen status in autumn. J. Hort. Sci. Biotechnol. 77:13-18.
Cheng, L. and G. Xia. 2004. Growth and fruiting of young 'Concord' grapevines in relation to reserve nitrogen and carbohydrates. J. Amer. Soc. Hort. Sci. 129:660-666.

Dirr, M.A. 2004. Hydrangea for American gardens. Timber Press, Portland, OR.

Dong, S., L. Cheng, C.F. Scagel, and L.H. Fuchigami. 2002. Nitrogen absorption, translocation and distribution from urea applied in autumn to leaves of young potted apple (Malus domestica) trees. Tree Physiol. 22:1305-1310.

Embleton, T.W., M. Matsumura, L.H. Stolzy, D.A. Devitt, W.W. Jones, R. EI-Motaium, and L.L. Summers. 1986. Citrus nitrogen fertilizer management, groundwater pollution, soil salinity and nitrogen balance. Appl. Agr. Res. 1:57-64.

Forshey, C.G. 1963. A comparison of soil nitrogen fertilization and urea sprays as sources of nitrogen for apple trees in sand culture. Proc. Amer. Soc. Hort. Sci. 83:32-45.

Guak, S., L. Cheng, and L.H. Fuchigami. 2001 Foliar urea pretreatment tempers inefficient $\mathrm{N}$ recovery resulting from copper chelate (CuEDTA) defoliation of apple nursery plants. J. Hort. Sci. Biotechnol. 76:35-39.

Hoagland, D.R. and D.I. Arnon. 1950. The waterculture method for growing plants without soil. California Agricultural Experiment Station Circular. p. 347.

Howell, G.S., B.G. Stergios, and S.S. Stackhouse. 1978. Interrelation of productivity and cold hardiness of Concord grapevines. Amer. J. Enol. Viticul. 29:187-191.

Kang, S.M. and J.S. Titus. 1980. Qualitative and quantitative changes in nitrogen compounds in senescing leaf and bark tissue of the apple. Physiol. Plant. 50:285-290.

Midcap, J.T. 1998. Hydrangea flower color. Center for Applied Nursery Research 1998 Research Reports. The Center for Applied Nursery Research, Univ. of Georgia. 26-29.

Millard, P. 1995. Internal cycling of nitrogen in trees. Acta Hort. 383:3-13.

Millard, P. 1996. Ecophysiology of the internal cycling of nitrogen for tree growth. J. Plant Nutr. Soil Sci. 159:1-10.

Millard, P. and G.H. Neilsen. 1989. The influence of nitrogen supply on the uptake and remobilization of stored $\mathrm{N}$ for the seasonal growth of apple trees. Ann. Bot. (Lond.) 63:301-309.
O'Kennedy, B.T., M.J. Hennerty, and J.S. Titus. 1975. Changes in the nitrogen reserves of apple shoots during the dormant season. J. Hort. Sci. 50:321-329.

Oland, K. 1960. Nitrogen feeding of apple trees by post-harvest urea sprays. Nature, UK 185:857.

Pan, R. and Z. Zhao. 1993. Synergistic effects of plant growth retardants and IBA on the formation of adventitious roots in hypocotyl cuttings of mung bean. Plant Growth Regulat. 14:1519.

Sanchez, E.E., T.L. Righetti, D. Sugar, and P.B. Lombard. 1990. Response of 'Comice' pear tree to a postharvest urea spray. J. Hort. Sci. 65:541-546.

Scholefield, P.B., T.F. Neales, and P. May. 1978. Carbon balance of the Sultana vines (Vitis vinifera $\mathrm{L}$.) and the effects of autumn defoliation by harvest-pruning. Aust. J. Plant Physiol. 5:561-570

Shim, K.K., J.S. Titus, and W.E. Splittstoesser. 1972. The utilization of post-harvest urea sprays by senescencing apple leaves. J. Amer. Soc. Hort. Sci. 97:592-596.

Spencer, P.W. and J.S. Titus. 1972. Biochemical and enzymatic changes in apple leaf tissue during autumnal senescence. Plant Physiol. 49:746-750.

Taylor, B.K., B. van den Ende, and R.L. Canterford. 1975. Effects of rate and timing of nitrogen applications on the performance and chemical composition of young pear trees, cv 'Williams'. Bon Chretien. J. Hort. Sci. 50: 29-40.

Thompson, J.A., G.D. Weston, and T.H. Thomas. 1983. The effects of daminozide on the levels of Indol-3yl-acetic acid and gibberellins in radish (Raphanus sativus L.) in relation to the control of storage root growth. Plant Growth Regulat. 1:269-278.

Titus, J.S. and S.M. Kang. 1982. Nitrogen metabolism, translocation, and recycling in apple trees. Hort. Rev. (Amer. Soc. Hort. Sci) 4:204-246.

Yeager, T.H., R.D. Wright, D. Fare, C.H. Gilliam, J.R. Johnson, T. Bilderback, and R. Zondag. 1993. Six state survey of container nursery nitrate nitrogen runoff. J. Environ. Hort. 11:206-208. 